\title{
Study of Cruise Practice English Classroom Teaching Based on the ESP Needs Analysis Theory
}

\author{
Zhen Yang \\ Tianjin Maritime College 300350 \\ 3049190377@qq.com
}

Key words: ESP needs analysis theory; cruise practice English; classroom teaching

\begin{abstract}
The development of science and technology drives the development of the cruise industry. Many foreign cruise companies begin to enter the Chinese market, which result in a shortage of cruise crew. English is the basic language cruise crew need to master, but also the important requirement of measuring the quality of cruise crew. From the features of cruise practice English, it belongs to the category of ESP teaching. This thesis mainly explores cruise practice English classroom teaching based on the ESP theoretical demand analysis, and combining the characteristics of teaching, it puts forward teaching measures and constructs classroom teaching model. It hopes to improve the efficiency of cruise practice English classroom teaching.
\end{abstract}

In recent years, the improvement of people's living standard stimulates the development of cruise tourist industry, expands the demand of cruise crew and also heightens the standard of cruise crew. English is the basic language cruise staffs have to master and crew's abilities of language organization as well as expression need to reach high standard. Therefore, in order to meet the demand of cruise industry, it is necessary to improve the quality of cruise practice teaching and train high-quality and high-level cruise crew.

\section{Overview}

1.1 Current Development Situation of Cruise Tourism. Tourism is an important part of China's economic growth and is a travel mode based on relaxation and amusement. Nowadays, more and more passengers travel by luxury cruise in China. What's more, many countries' cruise companies begin to develop in China and open up cruise travel routes. From the current development status, Chinese cruise industry lacks talents, especially cruise crew, which hinders the development of cruise industry. English is the basic language of cruise crew. In order to provide quality service for tourists from every country, it is essential to improve the level of cruise practice English.

1.2 ESP Course and Theoretical Analysis. ESP courses mean English for specific purposes. It is an English learning course based on the needs of a particular industry and learners. The course mainly trains English and professionals to meet all demands. After a comparison of EGP language course differences, Streveens puts forward the course characteristic demand of EGP that mainly includes the connection between courses and specific occupations and the teaching focus in accord with the requirements of application in particular fields. It is great different from GEP. Later, the characteristics of ESP are redefined again. The course is required to adopt activities in accord with practice to meet the demand of students and focus on students' language learning skills. Although the analysis perspective is different, all realize the combination of language skills and practice.

At present, ESP has experienced five periods of register analysis, rhetorical or discourse analysis, goal situation analysis, skills and learning strategy analysis and learning-centered. Demand analysis results from the stage of situation analysis and can analysis language by combining target occupation with learning situation. The defense of demand analysis contributes to the difference of different scholars' learning methods and key and difficult points.

Cruise practice English is the core curriculum cruise crew need to master and it belongs to the category of ESP. Students can be understood from different perspectives in this course and then the classroom teaching activities that conforms to the students' development are made. 


\section{Understanding Cruise Practical English}

2.1 Understanding Goal Situation. Firstly, understand the general requirement of English competence. Cruise belongs to luxury tourist liner, integrated with accommodation, catering, leisure, culture and civilization. It offers many jobs. Now every cruise company proposes the general requirement of staffs' English competence. As shown in following Table 1.

Table 1 the General Requirement of Different Cruise on Talents' English Competence

\begin{tabular}{|c|c|}
\hline Cruise Companies & The requirements of English competence \\
\hline Princess Cruise & $\begin{array}{c}\text { Good communication skills in English; receptionists speak in English } \\
\text { fluently. }\end{array}$ \\
\hline Star Cruise & $\begin{array}{l}\text { The frontcourt staffs have fluent English ability; The backcourt staffs } \\
\text { can adapt to the English working environment. }\end{array}$ \\
\hline $\begin{array}{l}\text { Royal Caribbean } \\
\text { Cruise } \\
\end{array}$ & $\begin{array}{l}\text { Good English communication management; English interview; } \\
\text { English resume }\end{array}$ \\
\hline Costa Cruise & $\begin{array}{l}\text { The manager is fluent in English; receptionists, security guards, etc. } \\
\text { are fluent in English; chiefs, cleaners are fluent in English. }\end{array}$ \\
\hline
\end{tabular}

From the above analysis, the majority of cruise companies have high requirement on the spoken English and listening of staffs. All of them require staffs to be fluent in English. According to the requirement of cruise crew, they can be divided into the frontcourt staffs and the backcourt staffs. The frontcourt staffs include managers, successors, waiters and security guards. And the backcourt staffs include cleaners, bartenders and chiefs. The frontcourt staffs have to communicate in English fluently; the backcourt staffs need to be proficient in English and adapt to the working environment. The language ability of the frontcourt staffs is slightly lower than the backcourt.

Secondly, analysis the language content in a specific working situation. Staffs working in different posts face different tourists and they are required to provide multiple services for tourists. In a practical application, the operating post is the focus, meanwhile, combining with the task situation demand in accordance with English course contents.

Cruise practice English refers to many contents, including all aspects of society. Hence, it is necessary to master English roundly, be equipped with a solid language foundation and carefully learn the custom and culture of every country. In short, staffs have to combine with the demand of their own jobs, strengthen the study of English knowledge and meet the requirements of various situations.

2.2 Analyzing Current Situation. Firstly, it is about learners' threshold levels and their abilities. Learners' threshold levels represent the learners' understanding of basic knowledge and their cognitive attitude toward the content having studied before learning. From the condition of cruise crew student admitted to Jiangsu province in 2013, a third-grade college mainly enrolled undergraduates would studied for 4 years and the rest enrolled junior college students would have a three-year study. The grade point average of National Matriculation English Test in Jiangsu province and the circumstance of last year are shown in following Table 2.

Table 2 the Whole Province's Grade Point Average of National Matriculation English Test

\begin{tabular}{|c|c|c|}
\hline categories & 2012 & 2013 \\
\hline Jiangsu's grade point average of National Matriculation English Test & 65.2 & 55.6 \\
\hline the matriculation grade point average of cruise crew major & 65.7 & 55.4 \\
\hline $\begin{array}{c}\text { the college freshmen's grade point average of National Matriculation } \\
\text { English Test }\end{array}$ & 70 & 59 \\
\hline
\end{tabular}

From the above analysis, cruise crews mainly come from vocational colleges. The matriculation grade point average of students whose major is cruise crew should not less than the average scores of two years and the grade of other departments are equal to the average scores. From current learning situation, students major in cruise crew not equipped with good basic knowledge of English reading and writing. They neglect the ability of listening and speaking, which results in learners' practical English competence not in accordance with teaching objectives.

Secondly, know the learning demand of learners. Generally, the demand can be known from 
learners' studying characteristics. Learning style, one of learners' learning modes, is made of learning strategies, learning tendencies and learning characteristics shown in the learning process. Learning characteristics mainly show the learners' cognition degree of the profession in virtue of life experience and study attention. This paper mainly does a questionnaire about freshmen and sophomores of cruise crew major. 98 questionnaires are collected. As shown in following Table 3.

Table 3 Students' Current Learning Situation and the Existence Problems

\begin{tabular}{|c|c|c|}
\hline Grades & Current Learning Situation and the Existence Problems & Percentage \\
\hline Freshmen & $\begin{array}{c}\text { Poor English basis, lack of self-confidence in language } \\
\text { learning }\end{array}$ & $52.4 \%$ \\
\hline & $\begin{array}{c}\text { Lack of cruise's and crew's knowledge, having little } \\
\text { knowledge of the basic positions and work requirements }\end{array}$ & $73.7 \%$ \\
\hline $\begin{array}{c}\text { Teaching methods are still subject to traditional teaching; } \\
\text { teaching is not creative. }\end{array}$ & $38.5 \%$ \\
\hline es & $\begin{array}{c}\text { Lack of teaching equipment, incapable of live-action } \\
\text { imitation, less practical courses }\end{array}$ & $86.7 \%$ \\
\hline & $\begin{array}{c}\text { Outdate teaching contents, not related to actual work demands } \\
\text { of professional vocabulary, incapable of learning western } \\
\text { culture in detail }\end{array}$ & $62.4 \%$ \\
\hline & $\begin{array}{c}\text { Hoping to carry out off-campus training and hands-on } \\
\text { operation }\end{array}$ & $76.2 \%$ \\
\hline & $\begin{array}{c}\text { Low passing rate of CET 4 and CET 6, poor English listening } \\
\text { and speaking }\end{array}$ & $52.4 \%$ \\
\hline
\end{tabular}

From the above analysis, the students majoring in cruise crew lack basic cruise knowledge. They cannot understand their own major's contents, lack confidence in language learning and have the vague concept of English. From the comparative analysis of freshmen with sophomores, sophomores have higher learning initiative and hope to carry out practical courses. However, because of their poor English abilities, many students still have difficult in learning. Meanwhile, there is stringent requirement on teaching environment, faculty and teaching contents.

2.3 Analysis of Learning Situation. Firstly, in recent years, many vocational schools open cruise crew major, construct the structure of cruise crew department and make objective of talent cultivation. They cultivate talents mainly from the application of skills, students' general quality and vocational certificates. And they set up impeccable courses and system to meet the demands of cruise crew. Meanwhile, they realize the combination of theory and practice teaching and publish professional learning materials. But these colleges still have problems in teaching, which can be analyzed from two aspects. On the one hand, the number of double - certificate type teachers is relatively small. At this stage, many colleges strengthen the construction of cruise professional teachers and introduce highly educated talents to teaching. However, these talents lack practical experience so that they only educate students from the book. Every college can organize cruise trainers to participate in training related to cruise industry. In necessity, colleges can recruit experienced practitioners to be their part-time teachers. On the other hand, there is in shortage of training places. From the current situation of the colleges that implements cruise teaching, there are a few simulation training rooms, which cannot satisfy students' practice demand and results in the poor application of knowledge. In order to improve students' practice ability, simulation facility such as antechamber, dining room and cabin can be constructed. It leads students do operation and enhances their professional ability.

\section{Enlightenment of Cruise Practice English Classroom Teaching Based on the ESP Needs}

3.1 Reinforcement of Cruise Knowledge Teaching. At present, China opens see travel lately. Many students know little about cruise working environment and the background. So they are not familiar with the needs of cruise restaurants, bars and entertainment and other types of work. 
Therefore, integrated with this situation, vocational colleges can implement the training mode of talents joint training and order employment to integrate cruise enterprises into the practical teaching of vocational colleges and achieve a combination of business and school education. Employers can directly go to the classroom teaching and introduce the details of the cruise crew requirements and basic knowledge to make students be familiar with the cruise crew requirements and require themselves strictly. Besides, the application of modern multimedia teaching facilities into teaching makes students master the cruise live-action and improve their understanding of the cruise crew work.

3.2 Using the teaching model of EGP $+\mathbf{E S P}+\mathbf{X}$. From the present situation of cruise crew professional teaching, now the professional education of cruise crew is mainly focus on vocational colleges. The weakness of students' English knowledge increases the difficulty of cruise practical English learning. So colleges can carry out effective English teaching based on general English. According to the characteristics of vocational college cruise crew, the teaching of cruise spoken language can be increased to achieve the joint teaching of EGP and ESP. The full usage of the two ways' the characteristics improves the effect of cruise practical English classroom teaching. X means that combining students' English basis, English learning needs, cruise work needs and their own learning characteristics, it is possible to make students choose their favorable jobs independently and know their learning direction clearly. For example, they do analysis from restaurants, bars, rooms and make a plan of learning Cruise practical English posts and other content to improve their English level.

3.3 The Implement of Project Classroom Teaching. Project classroom teaching refers to a teaching method that teachers and students cooperate together to teach or learn centered on established project and make use of every means to achieve project requirements in terms of project objectives, so that students can join the whole process of project directly. At present, the revolution of higher vocational education focuses on task and realizes the combination of English language skills and English service by project-driven teaching. The teaching effect is relatively ideal. Higher vocational education mainly focuses on task-driven, so it can teach by group work. Teaching contents can be divided into many modules in practical training, which brings new practice experience to students and lead students learn cruise practice English knowledge positively.

3.4 Evaluating Classroom Effect by Using Formative Assessment. Traditional examination and interview only check students' English basic knowledge and reflect students' theory level, which is hard to know the students' language communicative ability. Formative assessment mainly focuses on classroom assessment. It can assess students' communicative ability in real linguistic context and provide students' learning for teachers. And then the teaching method in accordance with students' development can be made and students' comprehensive language competence is improved. Firstly, classroom evaluation standard should be made. That classroom evaluation is a reference test need to be note. Bachman language communicative ability test is the focus. Classroom evaluation is made in terms of strategy ability, psychological and physiological mechanism and language competence. Secondly, evaluation methods should be chose appropriately. Classroom is the place of classroom evaluation. Teachers and students should participate positively in classroom teaching. Students should be educated by creative methods. The language applied used should be evaluated and analyzed comprehensively. Finally, the evaluation tool should be chose appropriately. Now according to classroom teaching characteristics, the classroom evaluation tool mainly use classroom observation, students' files, weekly dialogue diary and interview. Classroom observation is the teaching of teaching behaviors and the implement of technique. Students' studying status can be recorded and assessed in time by utilizing students' files, which provides a reference for students' self-evaluation. In addition, the implement of conversation, interview and colloquium also improves students' ability of collecting and reorganize teaching process and feeds back the teaching information timely.

\section{Conclusion}

Cruise crew is a new major. Its core curriculum is practical English which belongs to the category 
of professional English learning. This paper, based on the ESP needs analysis theory, mainly introduces practical English classroom teaching in detail, and combing current situation of cruise crew teaching, put forwards some measures. This paper hopes to improve the quality of cruise practice English classroom teaching and cultivate comprehensive modern talents.

\section{Reference}

[1] Xie Jun: Classroom Teaching Curriculum Design Based on ESP Needs Theory-Taking an Example of Cruise Service English. Newspaper of Wuxi Vocational Technology College,6. (2015)

[2] Liu Ruiling: Higher Vocational Study of ESP Based on Needs Analysis Theory. Shandong Normal University,7. (2014)

[3] Zhang Tonghong: The Study of Vocational College English Teaching Revolution Based on ESP Theory. Central China Normal University, 3. (2015)

[4] Gao Mei: ESP and Context-The Practical Study of the Cooperative Teaching Method in English Spoken Teaching of Secondary Vocational School's Finance Major. East China Normal University, 1. (2014)

[5] Xiao Jian: The Practical Study of Higher Vocational College Cruise English Versatile Talents Cultivation. Maritime Education Research, 6. (2015)

[6] Xie Dan: The Practical Combination Of EGP and ESP in Higher Vocational College Cruise English Teaching. Testing Weekly, 6. (2016)

[7] Wang Dan: The Applied Analysis of Experience Type Teaching Mode in Cruise English Teaching. Good parent. 2. (2016) 